Research Article

\title{
Synthesis of dendrimer assisted cobalt nanoparticles and catalytic application in Heck coupling reactions in ionic liquid
}

\author{
M. S. Islam ${ }^{1}$ - M. A. S. Mia ${ }^{2}$
}

Received: 12 January 2020 / Accepted: 6 March 2020 / Published online: 17 March 2020

(c) Springer Nature Switzerland AG 2020

\begin{abstract}
A dendrimer based on diazine supported heterogeneous Cobalt nanoparticles (NPs) were synthesized by a reduction method whereas the dendrimer was produced between the reaction of 2,4,6-triamino-1,3-diazine and benzoyl chloride at $80^{\circ} \mathrm{C}$ for $8 \mathrm{~h}$. The SEM image of the dendrimer supported Co NPs displayed the globular and agglomerate spherical size and EDX assessment noted the existence of necessary cobalt ion while TG and DSC showed excellent thermal stability. XRD revealed that FCC configuration of Co NPs. By using the Debye-Scherrer formula, the average size of these Co NPs was calculated to $18.10 \mathrm{~nm}$ likewise it was found $7.00 \mathrm{~nm}$ by the TEM analysis. The dendrimer was also evaluated by IR, ${ }^{1} \mathrm{HNMR},{ }^{13} \mathrm{CNMR}$, Mass spectrophotometry, and elemental analysis. The catalytic effect of these nanoparticles catalyst has been studied for Heck coupling reactions in tetrabutylammonium bromide solution and observed excellent catalytic efficiency within very short reaction time ( $45 \mathrm{~min})$ and also reusable.
\end{abstract}

\section{Graphic abstract}

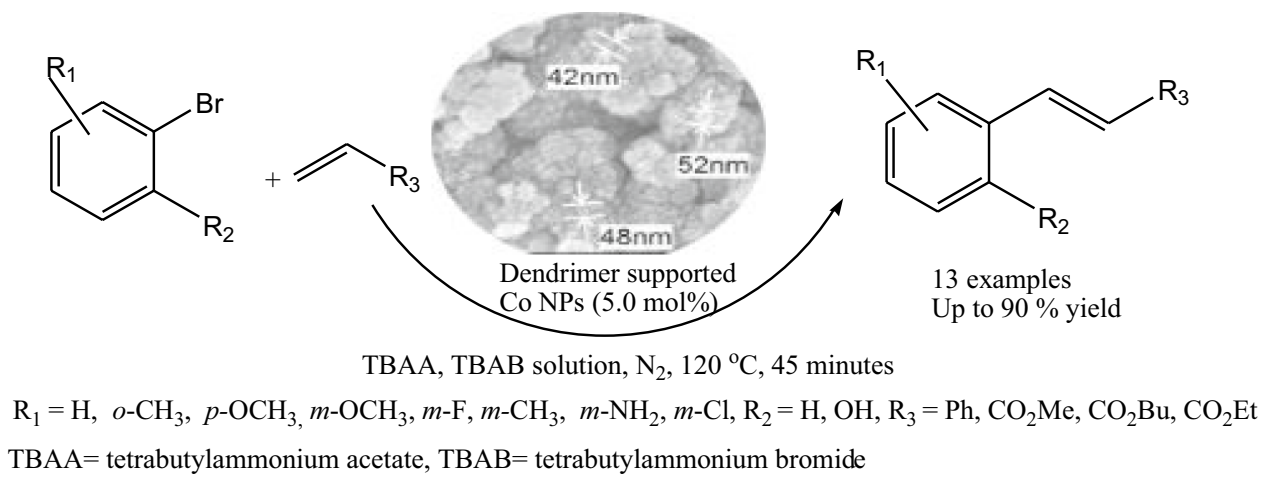

Keywords Dendrimer $\cdot$ Cobalt nanoparticles $\cdot$ Heck reaction $\cdot$ Ionic liquid $\cdot$ Tetrabutylammonium bromide $($ TBAB) Electronic supplementary material The online version of this article (https://doi.org/10.1007/s42452-020-2448-2) contains
supplementary material, which is available to authorized users.

M. S. Islam, sayedulbuet98@gmail.com; M. A. S. Mia, emsayid@gmail.com | ${ }^{1}$ Department of Chemistry, Faculty of Engineering, Bangladesh University of Engineering and Technology (BUET), Dhaka 1000, Bangladesh. ${ }^{2}$ Department of Applied Chemistry and Chemical Engineering, Faculty of Engineering and Technology, University of Dhaka, Dhaka 1000, Bangladesh. 


\section{Introduction}

The cross-coupling reaction for the formation of $\mathrm{C}-\mathrm{C}$ bond catalyzed by transition metal has been deliberated highly effective synthetic methods [1-4]. Adversely, the implementation of conventional catalyst palladium complexes for cross-coupling reactions has certain constraints in the case of poisonousness, price, non-reusability, and moisture sensitivity [5-7]. Furthermore, a significant decrease in catalytic efficiency of surface-active metal atoms was often induced due to various kinetic complications for instance agglomeration of metal particles during the reaction $[8,9]$. These issues can be achieved primarily through heterogeneous catalysts, the application of green reaction solvents and/or other transition metals that have garnered much attention in recent years, such as $\mathrm{Ni}, \mathrm{Cu}, \mathrm{Co}$ and $\mathrm{Fe}$ [10-14]. In organic synthesis, furthermore, cobalt-catalyzed couplings are of interest as cobalt is a cheap, easily accessible and one of the most efficient catalyst [15-18]. Recently some cobalt-based catalysts were recorded for the Heck reaction [19-21]. Also, metal nanoparticles of metal play a significant participation as the real catalyst or as a source of catalyst in many synthetic procedures. Recently, nanostructures have become one of the fastest issues owing to their innovative characteristics that are individual from those of their substance counterparts [22]. Due to their exceptional physical and chemical characteristics, which are of concern to fundamental science studies and prospective technological applications in catalysts, magnetic liquids and magnetic recording media, significant focus has been concentrated on the studies of nanosized magnetic materials such as $\mathrm{Fe}, \mathrm{Co}$, and $\mathrm{Ni}$ over the past decade [23-26].

In addition, dendrimer encapsulated metal NPs are used in a multitude of implementations notably drug delivery and catalysis $[27,28]$. By using the dendrimer template method the synthesis of dendrimer supported nanoparticle for catalysis has considerable advantages: (1) producing well-defined NPs with uniform shape and structure (2) leading in reliable catalytic locations available, (3) embedded NPs in dendrimer are also retained within the dendrimers, (4) restricting agglomeration causing in surface area preservation and a successive boost in the lifetime of the catalyst [29,30]. Moreover, ionic liquids (ILs) are an appealing solvent for nanoparticles in catalytically efficient transition metal manufacturing and retention. More notably, it is possible to produce ILs that include coordinating groups [31], for instance, with either the nitrile groups of the cation or anion (CN-IL). Palladium nanoparticles have been observed to be greater supported in CN-IL compared to nonfunctional ionic liquids in various $\mathrm{C}-\mathrm{C}$ coupling reactions catalyzed by a palladium catalyst; thus, improved catalytic activity and recyclability are achieved [32, 33].

According to these factors into consideration, and as an aspect of ongoing work to improve reliable green catalytic [34-36] synthetic method of diazine-based dendrimer supported monometallic Co NPs without phosphine ligand in the presence of tetrabutylammonium bromide (TBAB) solution as ionic solvent and base of tetrabutylammonium acetate (TBAA) for carbon-carbon cross-coupling reaction as revealed by Heck coupling reactions has been established.

\section{Results and discussion}

\subsection{Synthesis and characterization}

Dendrimer 3 was synthesized from the reaction of 2,4,6-triamino-1,3,-diazine 1 with benzoyl chloride 2 at $80{ }^{\circ} \mathrm{C}$ for $8 \mathrm{~h}$ (Scheme 1). The structure of the compound was established by IR, ${ }^{1} \mathrm{H}$ NMR, ${ }^{13} \mathrm{C}$ NMR, Mass

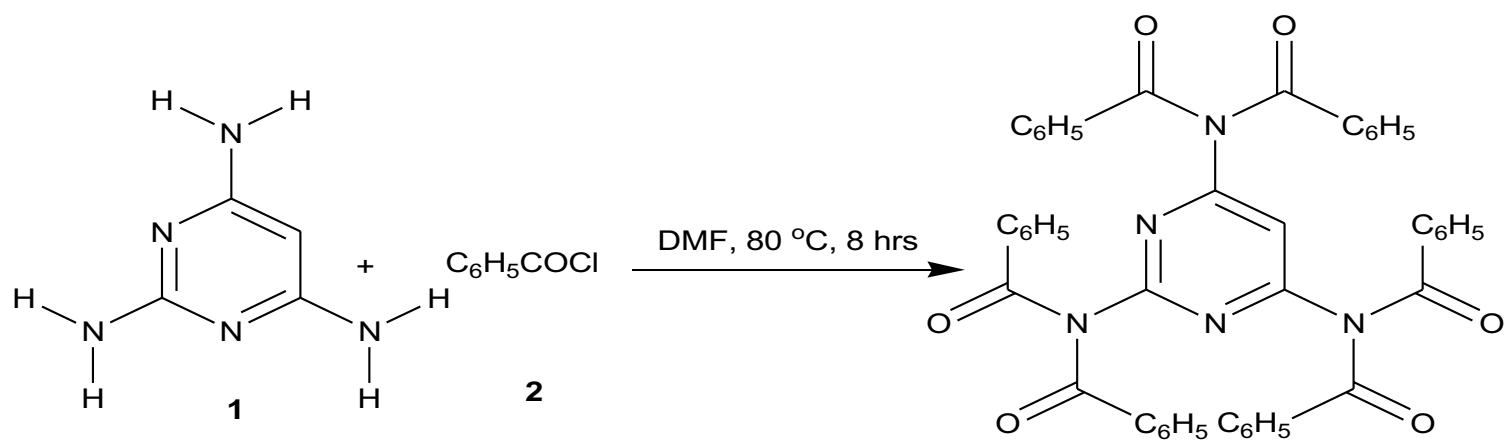

Scheme 1 Synthesis of 2,4,6-Tris(di-benzamido)-1,5-Diazine (dendrimer) 3 


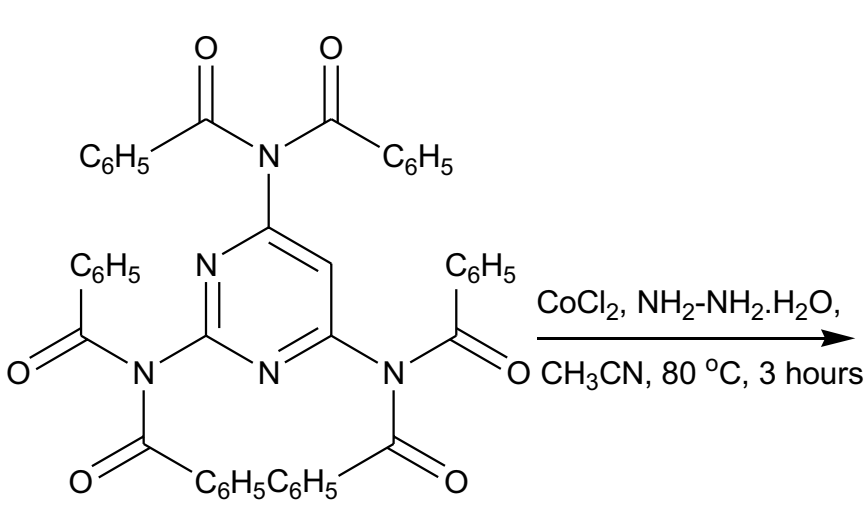

3

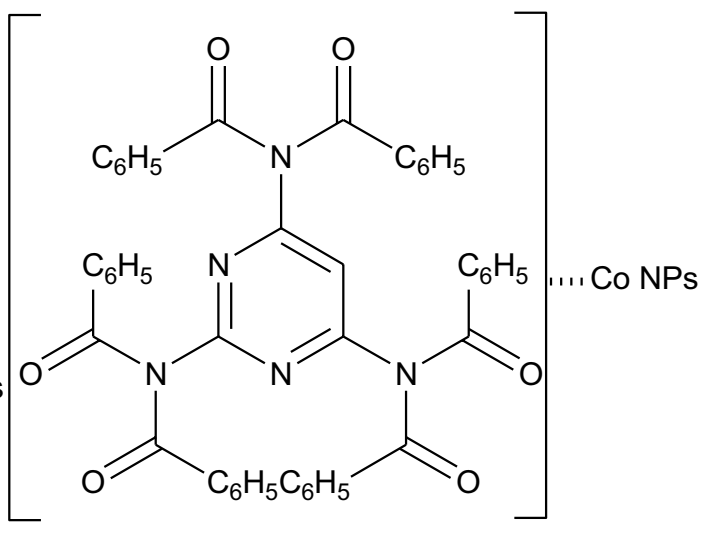

Dendrimer 3 supported Co NPs 4

Scheme 2 Synthesis of dendrimer (3) supported Co NPs 4

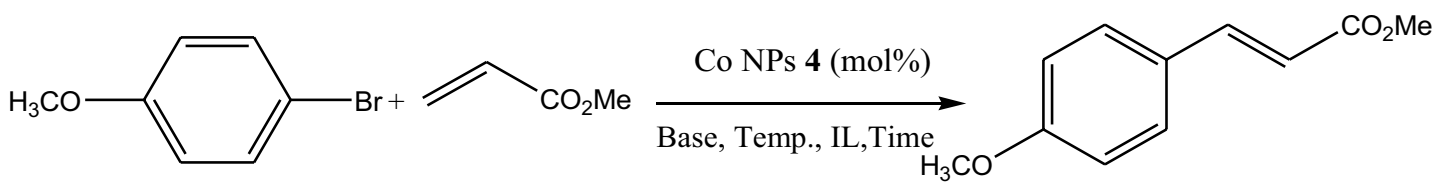

Scheme 3 A general model reaction between 4-bromoanisol and methylacrylate catalyzed dendrimer (3) supported Co NPs 4

spectrophotometry and also elementary analysis (S1-S4 in the supporting information).

Compound 3's structure was corroborated by the existence of vital peaks in the IR spectrum. The peak at the stretching stripe of 3035 and $1535 \mathrm{~cm}^{-1}$ stated the presence of aromatic $\mathrm{C}-\mathrm{H}$ and aromatic $\mathrm{C}=\mathrm{C}$ respectively, while the peak at $1620-1780 \mathrm{~cm}^{-1}$ deliver the $\mathrm{C}=\mathrm{O}$ band. Furthermore, it is considerable that there is no N-H fetter nigh $3400-3200 \mathrm{~cm}^{-1}$ that has been shown to have transformed $1^{\circ}$ amino group of triazine into $3^{\circ}$ amido group. The structure of dendrimer 3 was also recommended by the ${ }^{1} \mathrm{H}$ NMR and ${ }^{13} \mathrm{C}$ NMR spectra. In the ${ }^{1} \mathrm{H}$ NMR peak, there is no $\mathrm{NH}$ or $\mathrm{NH}_{2}$ tie that further characterized the structure of compound $\mathbf{3}$. The molecular ion peak 748.25 (100) [M]+ by MALDI-TOF MS and the presence of the required element by elementary analysis also ratify the makeup of compound $\mathbf{3}$.

Typically, dendrimer supported metal NPs were prepared from metal salts or complexes by chemical reduction with $\mathrm{LiBH}\left(\mathrm{C}_{2} \mathrm{H}_{5}\right)_{3}, \mathrm{~N}_{2} \mathrm{H}_{4} \cdot \mathrm{H}_{2} \mathrm{O}, \mathrm{NaBH}_{4}, \mathrm{H}_{2}$, etc. [37, 38] or by UV irradiation, [34, 39] or by decomposition (thermal, microwave, ultra-sound, etc.) $[35,36]$. Here it was followed very simple chemical reduction method by hydrazine monohydrate as the following Scheme 2 .

The dendrimer supported monometallic Co NPs 4 were described by various physicochemical methods such as IR, SEM, EDX, XRD, TEM, TGA, and DSC (Schemes 3 and 4).

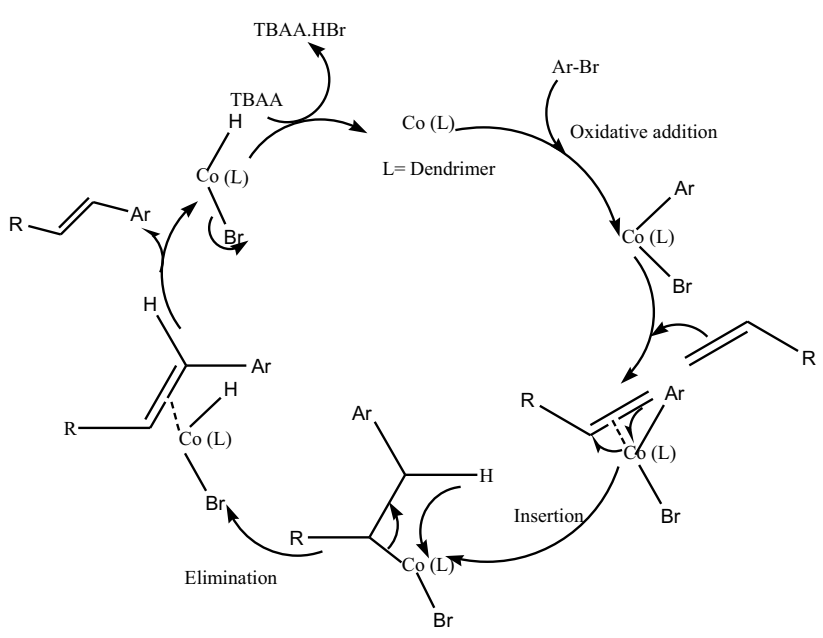

Scheme 4 Plausible mechanism of Heck reaction catalyzed by catalyst 4

All the required peaks of dendrimer 3 were present in the IR spectrum of the dendrimer supported Co NPs 4 (S 5 in the supporting information) and a small change of the peak position of $\mathrm{C}=\mathrm{O}$ group that might be induced due to steric effect between Co NPs and CO group. However, these observations of IR analysis indicated the formation of dendrimer 3 supported Co NPs 4. 


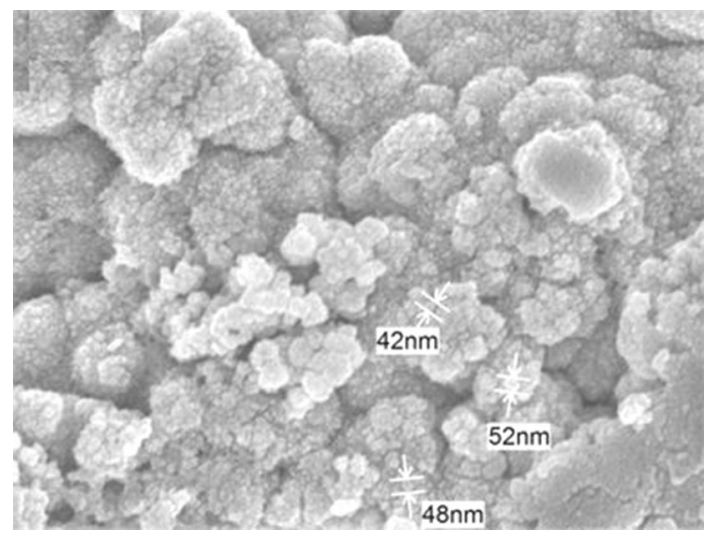

Fig. 1 SEM image of dendrimer (3) supported Co NPs 4

The SEM image of these nanoparticles $\mathbf{4}$ displayed the agglomerate globular and spherical size of the particles (Fig. 1).

Fig. 2 EDX analysis of dendrimer (3) supported Co NPs 4
The existence of cobalt was $71.25 \%$ of mass and $35.25 \%$ of atom of the synthesized diazine based dendrimer supported Co NPs 4 (Fig. 2) was found by EDX analysis. It was taken the weight ratio of the prepared dendrimer 3 and cobalt chloride as 1:3.3 ratio as well as it was observed from EDX analysis of the synthesized dendrimer supported Co NPs that the mass ratio between dendrimer and Co NPs was 1: 2.02. Also, no chlorine was observed in the dendrimer supported Co NPs. It was revealed from these observations that the synthetic procedure was successful for the preparation of dendrimer supported Co NPs 4.

The XRD illustration (Fig. 3) also described the particle shape and size of the diazine-based Cobalt NPs. Three notable peaks of FCC Cobalt nanoparticles were associated to (111), (110) and (220) at $43.30^{\circ}, 54.50^{\circ}$ and $75.50^{\circ}$ respectively with corresponding to the Cobalt FCC JCPDS \#15-0806 standard JCPDS powder diffraction card [40]. From the XRD graph, the average particle size of $18.10 \mathrm{~nm}$
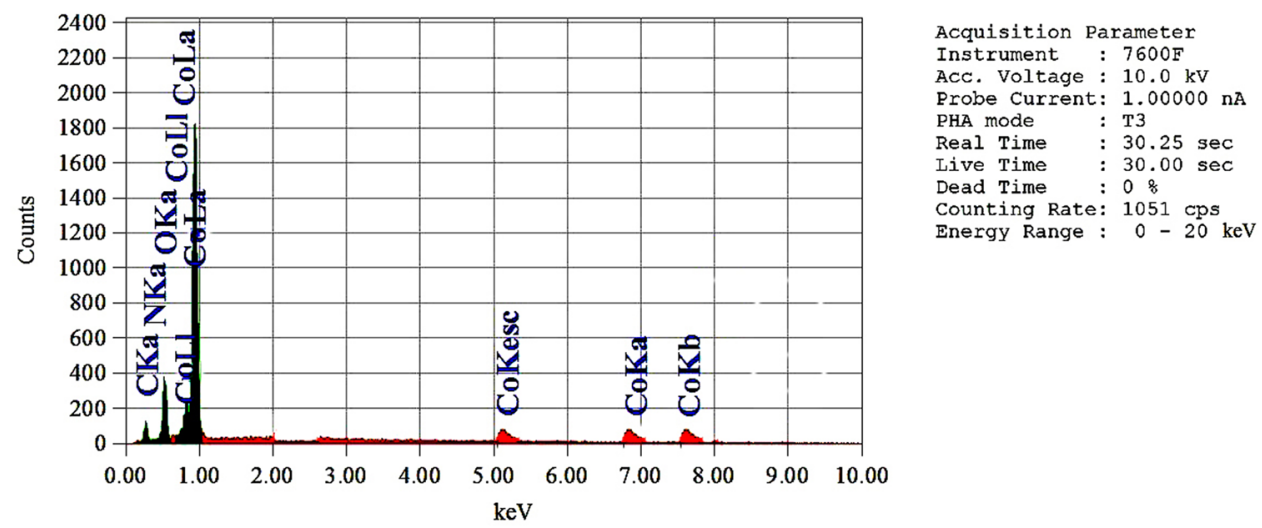

ZAF Method Standardless ouantitative Analysis

Fitting Coefficient : 0.0858

$\begin{array}{rrrrrrrrr}\text { Element } & \text { (keV) } & \text { Mass } & \text { Sigma } & \text { Atomo } & \text { Compound } & \text { Masso } & \text { Cation } & \text { K } \\ \text { C K } & 0.277 & 12.24 & 0.06 & 32.05 & & & & 4.5664 \\ \text { N K } & 0.392 & 0.94 & 0.10 & 2.11 & & & & 1.0853 \\ \text { O K } & 0.525 & 15.57 & 0.12 & 30.59 & & & & 18.5103 \\ \text { Co L } & 0.930 & 71.25 & 0.38 & 35.25 & & & & 75.8380\end{array}$

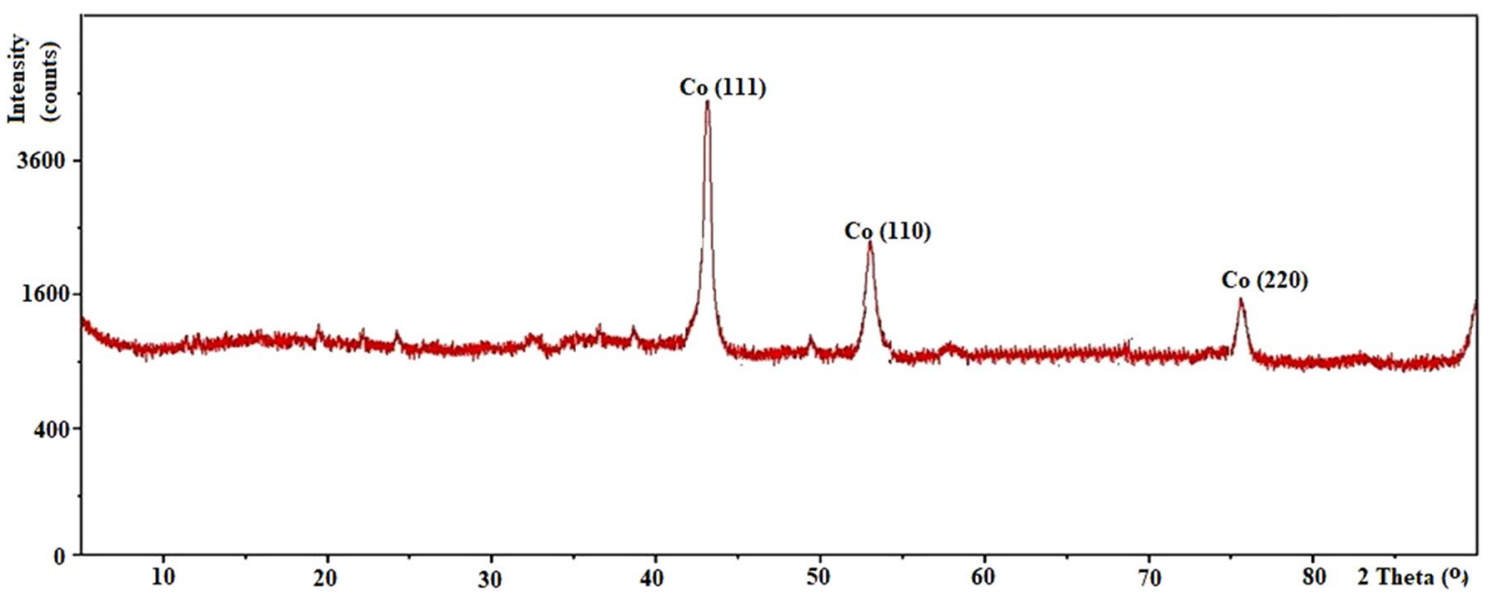

Fig. 3 XRD analysis of dendrimer (3) supported Co NPs 4 
a

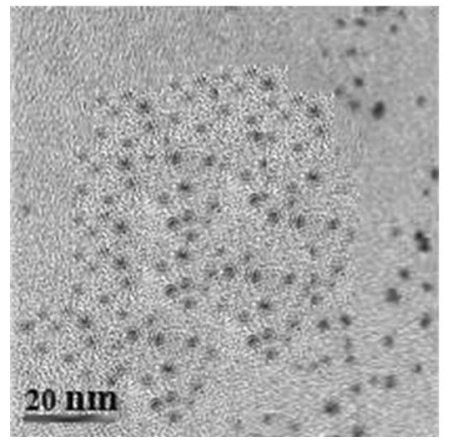

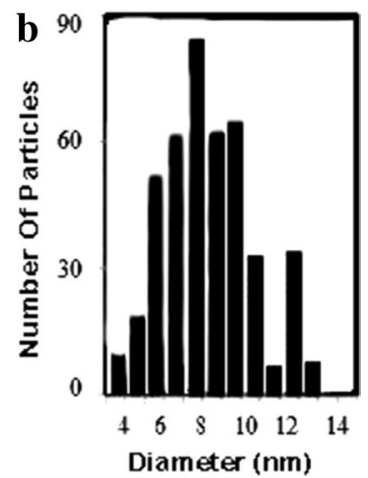

Fig. 4 a TEM image of Co NPs 4. b Average particle size of Co NPs 4

calculated by the Debye-Scherrer formula while the average particle size of the NPs was $7.00 \mathrm{~nm}$ (Fig. 4b) observed from the TEM analysis.

Thermal constancy is one of the key features of catalyst in order to sustain their activity in long reaction times and high temperature. It was detected from the TG and DSC curves of cobalt NPs 4 (Fig. 5). The substrate of nanoparticles varies with its framework and shape with the increasing of temperature and is evaluated by the thermo-gravimetric diagram according to the weight reduction of these components. It was identified from the TG curve that compound 4's total weight loss from 220 to $258{ }^{\circ} \mathrm{C}$ and the DSC values were just about analogous to the TG values. The melting point from the DSC endothermic curve was indicated at about $220^{\circ} \mathrm{C}$. The final stage of decline disclosed catalyst 4's $12.10 \%$ ash residue.

\subsection{Catalytic performance of the dendrimer 3 assisted cobalt NPs 4}

The ionic liquid (IL) tetrabutylammonium bromide (TBAB) solution in which metal nanoparticles are dispersed represented as a good solvent as well as co-catalyst for example Heck reaction between aryl bromides and butyl methacrylate catalyzed by Pd-NPs with tetrabutylammonium acetate (TBAA) as a base at $120^{\circ} \mathrm{C}$ [41].

At first, a general model reaction between 4-bromoanisol and methyl acrylate to detect the optimized reaction conditions for the Heck reaction catalyzed by Co NPs 4 with a solvent of tetrabutylammonium bromide (TBAB) solution. The outcomes of the different reactions were summarized in Table 1.
Fig. 5 TG and DSC graphs of dendrimer (3) supported Co NPs 4
Table 1 Optimization of the model Heck reaction between 4-bromoanisol and methylacrylate catalyzed by catalyst 4

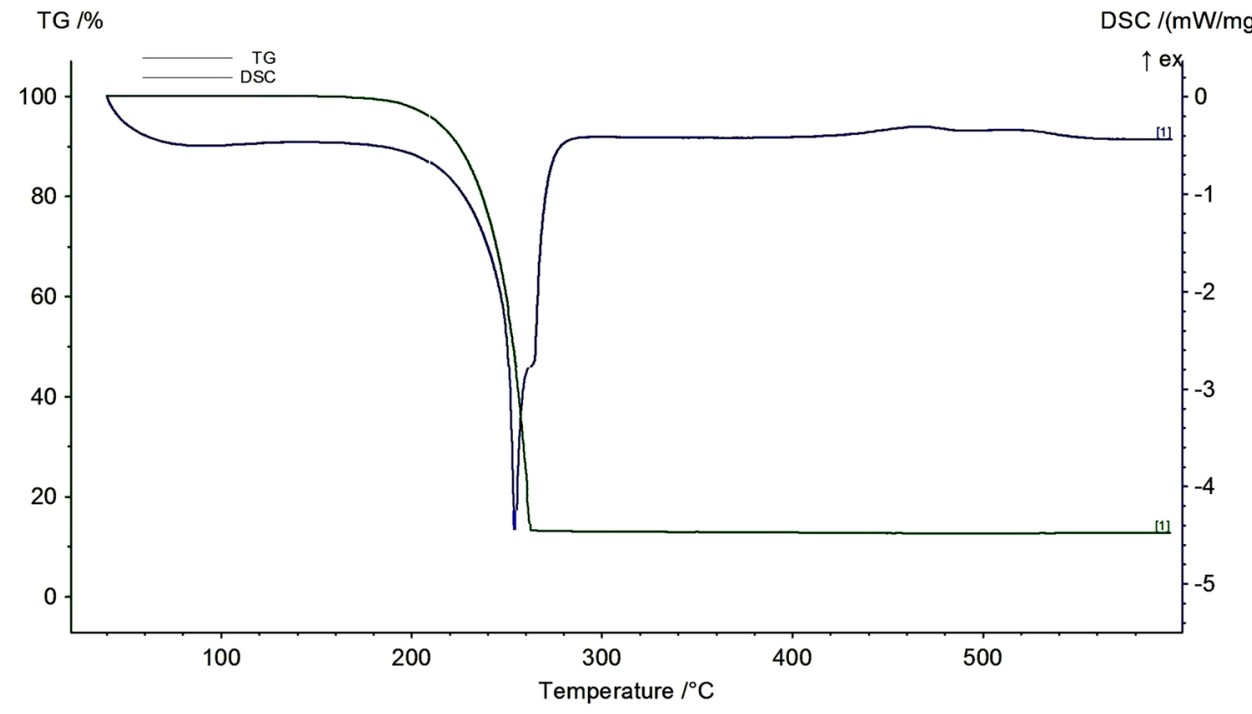

\begin{tabular}{lllllll}
\hline Entry & $\begin{array}{l}\text { Co-NPs } 4 \\
(\mathrm{~mol} \%)\end{array}$ & Base & Time $(\mathrm{min})$ & $\begin{array}{l}\text { Temperature } \\
\left({ }^{\circ} \mathrm{C}\right)\end{array}$ & Solvent & Yield (\%) \\
\hline 1 & 3 & $\mathrm{NaOH}$ & 70 & 80 & TBAB & 30 \\
2 & 4 & $\mathrm{Na}_{2} \mathrm{CO}_{3}$ & 70 & 90 & TBAB & 33 \\
3 & 4 & $\mathrm{Et}_{3} \mathrm{~N}$ & 70 & 90 & TBAB & 40 \\
4 & 4 & $\mathrm{Bu}_{3} \mathrm{~N}$ & 70 & 100 & TBAB & 50 \\
5 & 5 & $\mathrm{TBAA}$ & 60 & 100 & TBAB & 65 \\
6 & 5 & TBAA & 55 & 110 & TBAB & 73 \\
7 & 5 & TBAA & 45 & 120 & TBAB & 89 \\
\hline
\end{tabular}


Reaction conditions: 4-bromoanisol ( $1 \mathrm{mmol})$, methylacrylate $(1.2 \mathrm{mmol})$, base tetrabutylammonium acetate (TBAA) $(1.5 \mathrm{mmol}), 45 \mathrm{~min}$, temperature $120^{\circ} \mathrm{C}$, Yields $\%$ was calculated on the basis of 4-bromoanisol; solvent tetrabutylammonium bromide (TBAB) solution $(5 \mathrm{~mL})$, reaction environment- nitrogen atmosphere.

Initially, when a coupling reaction with the use of 3.0 or $4.0 \mathrm{~mol} \%$ of Co NPs 4 as catalyst, 4 -bromo anisol $(1.0 \mathrm{mmol})$ with methyl acrylate $(1.2 \mathrm{mmol})$ with $\mathrm{NaOH}$, $\mathrm{Na}_{2} \mathrm{CO}_{3}$ or $\mathrm{Et}_{3} \mathrm{~N}, \mathrm{Bu}_{3} \mathrm{~N}$ (1.2 equivalent) about 70 min was occurred from 80 to $100^{\circ} \mathrm{C}$ temperature in the solvent of ionic liquid tetrabutylammonium bromide (TBAB) solution under nitrogen atmosphere, the coupling product was found up to $50 \%$ of yield (Table 1, Entries 1-4). Curiously, the reaction has shown a significant increase in the yield of products at $65 \%$ or $73 \%$ with 5.0 mol\% of Co NPs 4 with base TBAA and solvent TBAB solution by increasing temperature at $100^{\circ} \mathrm{C}$ or $110^{\circ} \mathrm{C}$ with reduced time about 60 or $55 \mathrm{~min}$ (Table 1, Entries 5, 6). However, the maximum outcome for the optimized conditions was observed by using 5.0 mol\% of the Co NPs 4 and TBAA as a base, and solvent TBAB solution for this above Heck coupling reaction under the nitrogen atmosphere at $120^{\circ} \mathrm{C}$ at $45 \mathrm{~min}$ (Table 1, Entry 7).

After optimizing the conditions of Heck reaction catalyzed by Co NPs 4, it was carried out the Heck coupling reaction of different aryl halogen derivatives on different olefins catalyzed by this catalyst to study the effect of different substituents of reagents on the yield\% of the coupling products. But it was not found any noteworthy variation of yield\% of coupling products for different aryl bromide derivatives and different olefins. A little amount of higher yield\% of the product was obtained for aryl bromides containing electron-donating substituents methyl and hydroxyl group shown in Table 2 .

Many studies have noted that the metal-catalyzed Heck reaction in the ionic fluid can provide an effective and easy path for the preparation of regioselective products by preventing the isomerization of certain conjugated dienes [42]. All the coupling products were found as regioselective trans-products supported by ${ }^{1} \mathrm{HNMR}$ spectra of coupling products and was not obtained any by-products. All the coupling products were analyzed by ${ }^{1} \mathrm{HNMR}$ and ${ }^{13} \mathrm{CNMR}$ spectra (S6-S31 in the supporting information.)

The vigorous sites of transition metal nanoparticles immobilized in ionic liquid are not readily oxidized and settled down due to the fact that all surface atoms are geta table for catalysis whether through the coordination or dislocation of the stabilizing agent or ligands [43].
While the solvent stabilizes the nanoclusters of metal, the base creates fast neutralization of $\mathrm{PdH}$ that inhibits the readmission of hydride to the products and avoids interconversion of olefin. As a result of these impact, TBAB and TBAA improve the rate of high output of products and abate the reaction time compared to exact Heck reaction without TBAB and TBAA [44].

Apart from the stabilizing impact of the ionic liquid [41, 45-48] on the metal nanoparticles and the regulation of the regioselectivity in the coupling mechanism, a further benefit in the usefulness of TBAA is the contain of the question ordinarily observed in the Heck reaction: that is, the sharp deactivation of the catalyst attributable to a arise in inorganic salt or ammonium halide levels obtained from metal hydride neutralization by inorganic or organic bases as tertiary amines $[49,50]$.

The mechanistic investigations of cobalt catalyzed Heck coupling reaction carried out recently by numerous researchers [51-53] described that alkyl halides induce the generation of the corresponding radical intermediates with the catalyst with the cobalt catalyst whereas alkenyl and aryl halides undergo non-radical oxidative addition in the mechanistic pathway. Based on these observations, we have proposed a plausible mechanism of catalyst 4 as following.

\subsection{Recoverability and reusability of the catalyst}

The recoverability and reusability of the catalyst 4 have been tested utilizing bromoanisol and methyl acrylate as substrates, and the yield\% has been included in Table 3 . The catalyst was recovered by centrifugation after each catalytic run followed by ethanol and acetone washing $(2 \times 3 \mathrm{~mL})$, and also recycled to further catalytic run. After being reused four times, the SEM analysis of the recovered catalyst (Fig. 6) has been taken and agglomerated surface morphology was found alike initial morphology and also the catalyst's constant performance, suggesting that the catalyst is not only effective enough for the Heck reaction but also very stable (Table 4).

The reaction was carried out with bromoanisol $(1.0 \mathrm{mmol})$, methyl acrylate $(1.2 \mathrm{mmol})$ and TBAA $(3 \mathrm{mmol})$ in TBAB solution in the presence of $5 \mathrm{~mol} \%$ Co NPs catalyst 4 at $120^{\circ} \mathrm{C}$.

Moreover, the catalytic activity of dendrimer supported Co NPs 4 was contrasted with other previously reported Co-NPs catalyst. It is observed that the reaction time in the presence of dendrimer supported Co NPs 4 is much shorter than the reported Co NPs and also cobalt-based catalysts. 
Table 2 Heck coupling reaction of different aryl bromides with different substitute of olefins catalyzed by catalyst 4

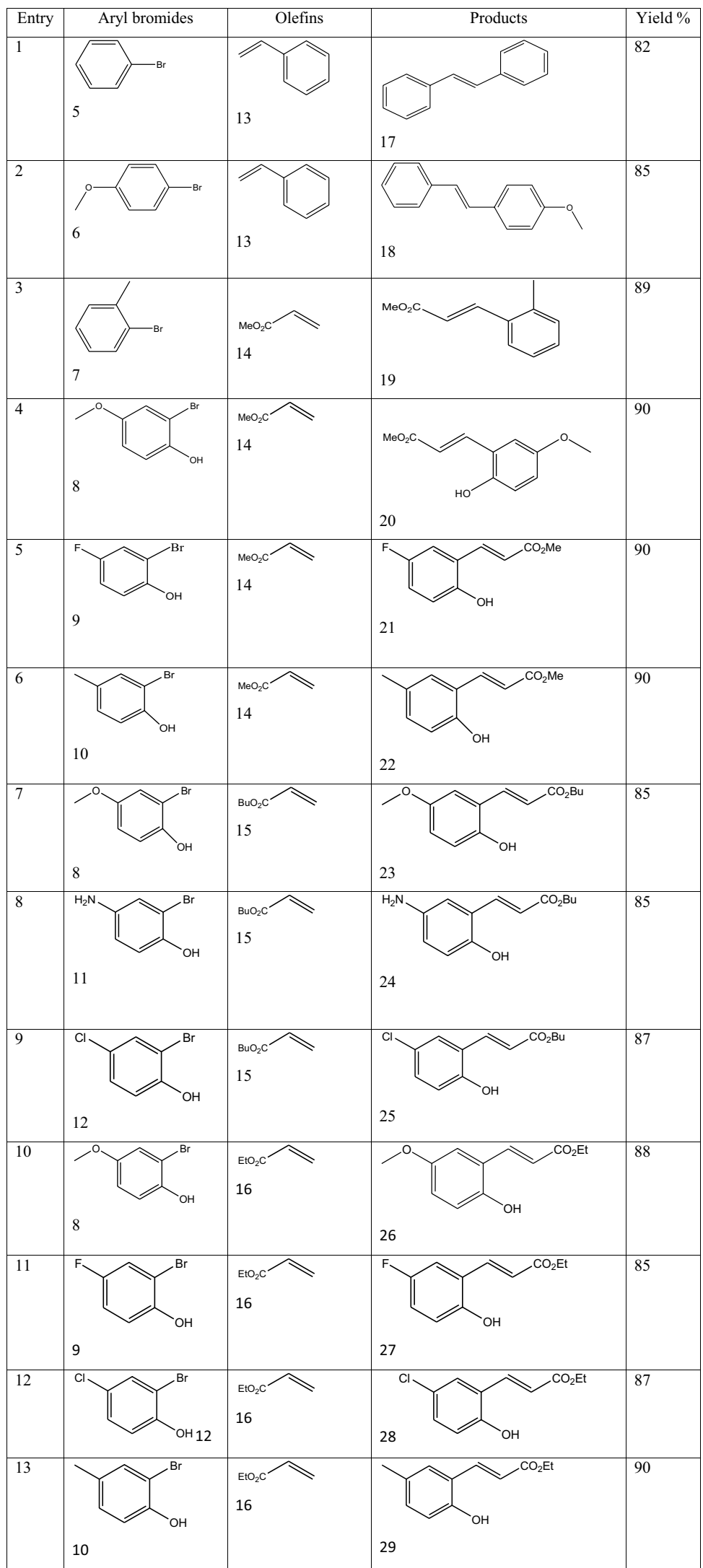

Yield\% was calculated based on aryl bromides 
Table 3 Yield\% of recyclable of dendrimer supported Co $\mathrm{NPs}^{\mathrm{a}} 4$

\begin{tabular}{ll}
\hline Run & ${\text { Yield }(\%)^{\text {b }}}^{\text {. }}$ \\
\hline 1 & 89 \\
2 & 84 \\
3 & 80 \\
4 & 77 \\
5 & 70 \\
\hline
\end{tabular}

${ }^{a}$ The reaction was carried out with bromoanisol $(1.0 \mathrm{mmol})$, methyl acrylate $(1.2 \mathrm{mmol})$ and TBAA (3 mmol) in TBAB solution in the presence of $5 \mathrm{~mol} \%$ Co NPs catalyst 4 at $120^{\circ} \mathrm{C}$

${ }^{\mathrm{b}}$ Yield \% was calculated on the basis of bromoanisol

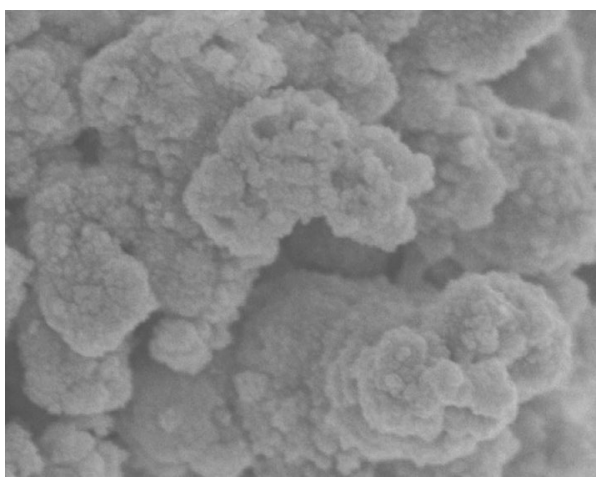

Fig. 6 SEM of the recovered dendrimer supported Co NPs 4

\section{Conclusion}

One of the overwhelmingly dominant goals of our study to find out an eco-friendly green synthetic reaction process for carbon-carbon bond forming reactions catalyzed with novel air-stable diazine based dendrimer supported cobalt nano catalyst in the presence of ionic liquid without any phosphine ligand within a short reaction time. We have developed an environment and eco-friendly novel diazine-based dendrimer supported cobalt NPs catalytic synthetic method for carbon-carbon cross-coupling reactions especially in the case of Heck coupling reactions with ionic liquid (TBAB) solution without any phosphine ligand whereas the cobalt NPs have been characterized with IR, SEM, EDX, XRD, TGA \& DSC and also dendrimer has been analyzed by IR, ${ }^{1} \mathrm{HNMR},{ }^{13} \mathrm{CNMR}$, Mass spectrophotometry and elemental analysis. The globular and agglomerate spherical size, as well as the presence of cobalt ion, were observed by SEM and EDX analysis while the FCC shape of the Co NPs was confirmed with XRD analysis. The average size of $18.10 \mathrm{~nm}$ and $7.00 \mathrm{~nm}$ of the Co NPs were determined with Debye-Scherrer formula and the TEM experiment respectively. This novel and ecofriendly dendrimer supported Cobalt nanoparticle (NPs) catalyst are estimated as an effective catalyst for the Heck coupling reactions with very short reactions times with ionic liquid without any hazard solvent as well as recovered and reused. However, this methodology is now investing for various cross-coupling reactions such as Suzuki, Sonogashira, stille etc.
Table 4 Comparison of the catalytic activity of various cobalt catalyst

\begin{tabular}{lllll}
\hline Entry & Catalyst (refs) & Reaction conditions & Time $(\mathrm{h})$ & Yield (\%) \\
\hline 1 & Nano Co [54] & $\mathrm{Co}(2 \mathrm{~mol} \%)$ in NMP at $130{ }^{\circ} \mathrm{C}$ & 14 & 78 \\
2 & $\mathrm{Co} / \mathrm{Al}_{2} \mathrm{O}_{3}[55]$ & $\mathrm{Co}(10 \mathrm{~mol} \%)$ in NMP at $150{ }^{\circ} \mathrm{C}$ & 24 & 56 \\
3 & Nano Co [56] & $\mathrm{Co}(2 \mathrm{~mol} \%)$ in NMP at $140{ }^{\circ} \mathrm{C}$ & 16 & 85 \\
4 & $\mathrm{Co-B}[57]$ & $\mathrm{Co}(5 \mathrm{~mol} \%)$ in DMF at $130{ }^{\circ} \mathrm{C}$ & 12 & 98 \\
5 & Co-NHC@MWCNTs [58] & $\mathrm{Co}(3.5 \mathrm{~mol} \%)$ in PEG at $80^{\circ} \mathrm{C}$ & 5 & 85 \\
6 & Co-IL@MWCNTs [59] & $\mathrm{Co}(5 \mathrm{~mol} \%)$ in toluene at $100^{\circ} \mathrm{C}$ & 3 & 87 \\
\hline
\end{tabular}




\section{Experimental}

\subsection{Materials and method}

All reagents as well as solvents for example tetrabutylammonium bromide (TBAB) solution and, tetrabutylammonium acetate (TBAA), methyl acrylate, butyl acrylate, styrene, 2, 4, 6-triaminopyrimidine; acetyl chloride and $\mathrm{CoCl}_{2}$ have been purchased from Sigma Aldrich and also used without purification. The melting point of all synthesized compounds was determined on Gallenkamp (England) in open capillary tubes. Shimadzu FTIR 8400 S Fourier Transformation Spectrophotometer infrared was used for the detection of IR spectrum with $\mathrm{KBr}$ pellets $\left(400-4000 \mathrm{~cm}^{-1}\right)$. ${ }^{1} \mathrm{H}$ NMR and ${ }^{13} \mathrm{C}$ NMR spectra had been taken at $500 \mathrm{MHz}$ and $125.76 \mathrm{MHz}$, respectively, on a JEOL instrument as well as BRUKER DPX-400 MHz and $100 \mathrm{MHz}$ spectrophotometers respectively. Relative to TMS, chemical shifts have been recorded. Silica gel 60 F 254 covered on 25 TCC sheets of aluminum was used for chromatography with a thin layer analysis (TLC). The columns were formed from silica gel $60 \mathrm{~N}$ (neutral, 40-100 $\mu \mathrm{M}$ ) chromatographic separation. The thermal stability of nanoparticles was detected with thermogravimetric analyzer (NETZSCH STA 449F3) within the range of 26 to $600^{\circ} \mathrm{C}$. Using aluminum oxide crucible, the thermogravimetric (TG) and differential scanning calorimetry (DSC) analysis were recorded at $10 \mathrm{ok} /$ min and at a flow rate of 40 and $60 \mathrm{~mL} / \mathrm{min}$ under a nitrogen atmosphere. The particle size and phase of Co NPs 4 were measured by PANANALYTICAL X-ray diffractometer (XRD). Scanning electron microscope (SEM), as well as Energy-dispersive X-ray spectroscopy (EDX) of NPs 4, were observed by JEOL-JSM-7600F. Transmission electron microscopy (TEM) analysis was accomplished by Philips CM12 transmission electron microscope (operating at $200 \mathrm{keV})$.

\subsection{Synthesis of 2,4,6-tris(di-benzamido)-1,3-diazine 3}

The mixture of $0.2 \mathrm{~g}(0.00159 \mathrm{~mol})$ 2,4,6-Triaminopyrimidine, $3 \mathrm{~mL}$ of benzoyl chloride was stirred at $80^{\circ} \mathrm{C}$ temperature in $5 \mathrm{~mL}$ of DMF in a $250 \mathrm{~mL}$ round bottom flask under a nitrogen atmosphere with reflux condition. At the starting of the reaction, the color of the reaction mixture was a clear solution and gradually it turned into light brown. The progress of the reaction was checked by thin-layer chromatography (TLC) and after $8 \mathrm{~h}$ it was completely converted into the light brown solid reaction mixture and was stopped by the addition of distilled water. After cooling the reaction mixture, it was filtered under suction on a Buchner funnel and washed with sufficient distilled water. Then the product was extracted with $\mathrm{CHCl}_{3}$. After the elimination of the solvent, it was crystallized with ethyl acetate and the desired compound $\mathbf{3}$ was found as light brown crystalline solid. Melting point is $130-132^{\circ} \mathrm{C}$, odorless and $92 \%$ of yield. IR (KBr): $v_{\max } 3035,1685,1675$, 1535,1350 and $1290 \mathrm{~cm}^{-1}$.

${ }^{1} \mathrm{H}$ NMR $\left(400 \mathrm{MHz}, \mathrm{CDCl}_{3}\right): 4.49(\mathrm{~s}, 1 \mathrm{H}), 6.75-7.23(\mathrm{~m}$, $18 \mathrm{H})$ and $8.45-8.50(\mathrm{dd}, 12 \mathrm{H}, J=8.0, J=8.8 \mathrm{~Hz}) .{ }^{13} \mathrm{C} \mathrm{NMR}$ $\left(125.76 \mathrm{MHz}, \mathrm{CDCl}_{3}\right): 128.60,129.46,130.34,133.35$ and $172.77 \mathrm{ppm}$. MALDI-TOF MS: $\mathrm{m} / \mathrm{z}(\%)=$ calcd. for $\mathrm{C}_{46} \mathrm{H}_{31} \mathrm{~N}_{5} \mathrm{O}_{6}: 749.77$; found 748.25 (100) [M]+, Anal. Calcd. (\%) for $\mathrm{C}_{46} \mathrm{H}_{31} \mathrm{~N}_{5} \mathrm{O}_{6}: \mathrm{C}, 73.69 ; \mathrm{H}, 4.17 ; \mathrm{N}, 9.34$; Found: $\mathrm{C}$, $73.65 ; \mathrm{H}, 4.10 ; \mathrm{N}, 9.30$.

\subsection{Synthesis of dendrimer compound 3 supported Co nanoparticles 4}

To synthesize dendrimer compound $\mathbf{3}$ supported Co nanoparticles $4,0.100 \mathrm{~g}$ of 2,4,6-Tris (di-benzamido)-1,3-diazine $3(0.133 \mathrm{mmol}), 0.337 \mathrm{~g}$ of $\mathrm{CoCl}_{2}(2.6 \mathrm{mmol}), \mathrm{NH}_{2}-\mathrm{NH}_{2} \cdot \mathrm{H}_{2} \mathrm{O}$ $(1.2 \mathrm{mmol})$ were stirred in $\mathrm{CH}_{3} \mathrm{CN}(8 \mathrm{~mL})$ in a round bottom flask under reflux conditions. The $\mathrm{NaOH}$ solution (0.3 M) was added gradually to the reaction due to keeping up the solution $\mathrm{pH} 11$ and the suspension was forcefully stirred with a magnetic stirring bar at $90^{\circ} \mathrm{C}$ for $3 \mathrm{~h}$. After stopping and settling down the reaction, the black residue was obtained. In addition, after centrifugation (3500 rpm for $10 \mathrm{~min}$ ) of the reaction mixture, the residue was filtered, washed with distilled water and acetone and dehydrated overnight in an oven at $120^{\circ} \mathrm{C}$. IR (KBr): $\mathrm{v}_{\max } 3032,1687$, $1602,1577,1304$ and $1299 \mathrm{~cm}^{-1}$.

\subsection{Catalytic application of Co nanoparticles 4 for Heck reactions}

General procedure-A mixture of $1.0 \mathrm{mmol}$ of aryl bromides, $1.2 \mathrm{mmol}$ of different substitutes of olefins, $5.0 \mathrm{~mol} \%$ of $\mathrm{Co}$ NPs 4, TBAA as a base $(1.5 \mathrm{~mL})$, and TBAB solution $(5.0 \mathrm{~mL})$ as a solvent was poured into a round bottom flask. Then at $120^{\circ} \mathrm{C}$ under reflux conditions about $45 \mathrm{~min}$, it was stirred as well as the reaction was monitored and controlled by thin-layer chromatography (TLC). At the starting of the reaction, the colored of the reaction mixture was light brown gradually it was changed into brown colored solution of reaction mixture. The progress of the reaction was checked by TLC and after the completion of the reaction, the reaction solution was completely converted into light brown reaction mixture. Then it was cooled at room temperature and after removing the solvent, the product was extracted with $\mathrm{CHCl}_{3}(20 \mathrm{ml})$ and the organic layer was also filtered, dried with $\mathrm{MgSO}_{4}$. Finally, the product was purified through silica gel column chromatography (ethyl acetate: hexane, 5:1). 


\subsubsection{Synthesis of (E)-1,2-diphenylethene 17 [60]}

Yield\%-82, Mol. Wt.: $180.25, \mathrm{mp} .76-78{ }^{\circ} \mathrm{C},{ }^{1} \mathrm{H}$ NMR (400 MHz, $\left.\mathrm{CDCl}_{3}\right), \delta 7.00(\mathrm{~s}, 2 \mathrm{H}, \mathrm{CH}=\mathrm{CH}) ; 7.46-7.50(\mathrm{~m}, 4$ $\mathrm{H}, \mathrm{Ar}-\mathrm{H}) ; 7.64-7.68(\mathrm{~m}, 4 \mathrm{H}, \mathrm{Ar}-\mathrm{H}) ; 7.76(\mathrm{~d}, 2 \mathrm{H}, J=7.2 \mathrm{~Hz}$, $\mathrm{Ar}-\mathrm{H}) ;{ }^{13} \mathrm{C}$ NMR $\left(100 \mathrm{MHz}, \mathrm{CDCl}_{3}\right): \delta 127.56(\mathrm{CH}=\mathrm{CH})$, 128.61 (Ar-C), 128.11 (Ar-C), 129.85 (Ar-C), $138.46(\mathrm{Ar}-\mathrm{C})$; Anal. Calcd. (\%) for $\mathrm{C}_{14} \mathrm{H}_{12}: \mathrm{C}, 93.29 ; \mathrm{H}, 6.71$; Found: $\mathrm{C}, 93.20$; $H, 6.67$.

\subsubsection{Synthesis of 1-methoxy-4-styrylbenzene 18 [60]}

Yield\%-85, Mol. Wt.: 210.27 , mp. $135-137{ }^{\circ} \mathrm{C},{ }^{1} \mathrm{H}$ NMR $\left(400 \mathrm{MHz} \mathrm{CDCl}_{3}\right), \delta 3.50\left(\mathrm{~s}, 3 \mathrm{H}, \mathrm{OCH}_{3}\right) ; 6.38(\mathrm{~d}, 2 \mathrm{H}$, $J=12.0 \mathrm{~Hz}, \mathrm{Ar}-\mathrm{H}) ; 6.57(\mathrm{~d}, 1 \mathrm{H}, J=16 \mathrm{~Hz}, \mathrm{CH}=\mathrm{CH}) ; 6.86(\mathrm{~d}, 1$ $\mathrm{H}, J=16 \mathrm{~Hz}, \mathrm{CH}=\mathrm{CH}) ; 7.29-7.38(\mathrm{~m}, 1 \mathrm{H}, \mathrm{Ar}-\mathrm{H}) ; 7.57(\mathrm{t}, 2 \mathrm{H}$, $J=11.2 \mathrm{~Hz}, \mathrm{Ar}-\mathrm{H}) ; 8.18(\mathrm{t}, 4 \mathrm{H}, J=18.0 \mathrm{~Hz}, \mathrm{Ar}-\mathrm{H}) .{ }^{13} \mathrm{C} \mathrm{NMR}$ $\left(100 \mathrm{MHz}, \mathrm{CDCl}_{3}\right): \delta 53.31\left(\mathrm{OCH}_{3}\right), 113.29(\mathrm{Ar}-\mathrm{C}), 125.32$ $(\mathrm{Ar}-\mathrm{C}), 125.76(\mathrm{Ar}-\mathrm{C}), 127.56(\mathrm{CH}=\mathrm{CH}), 127.66(\mathrm{Ar}-\mathrm{C})$, $129.53(\mathrm{Ar}-\mathrm{C}), 129.83(\mathrm{Ar}-\mathrm{C}), 131.25(\mathrm{Ar}-\mathrm{C}), 138.34(\mathrm{Ar}-\mathrm{C})$, 158.40 (Ar-C); Anal. Calcd. (\%) for $\mathrm{C}_{15} \mathrm{H}_{14} \mathrm{O}: \mathrm{C}, 85.68 ; \mathrm{H}, 6.71$; Found: $\mathrm{C}, 85.60 ; \mathrm{H}, 6.68$.

\subsubsection{Synthesis of (E)-methyl 3-o-tolylacrylate 19 [60]}

Yield\%-80, Mol. Wt.: $176.21 \mathrm{mp} .120-122{ }^{\circ} \mathrm{C},{ }^{1} \mathrm{H}$ NMR $\left(400 \mathrm{MHz} \mathrm{CDCl}_{3}\right), \delta 2.40\left(\mathrm{~s}, 3 \mathrm{H}, \mathrm{CH}_{3}\right) ; 3.83\left(\mathrm{~s}, 3 \mathrm{H}, \mathrm{OCH}_{3}\right)$; $6.48(\mathrm{~d}, 1 \mathrm{H}, J=16.0 \mathrm{~Hz}, \mathrm{CH}=\mathrm{CH}) ; 7.33-7.69(\mathrm{~m}, 3 \mathrm{H}, \mathrm{Ar}-\mathrm{C})$; 7.83-7.90 (m, $1 \mathrm{H}, \mathrm{Ar}-\mathrm{C}) ; 8.34(\mathrm{~d}, 1 \mathrm{H}, J=8.0 \mathrm{~Hz}, \mathrm{CH}=\mathrm{CH}) ;{ }^{13} \mathrm{C}$ $\operatorname{NMR}\left(100 \mathrm{MHz}, \mathrm{CDCl}_{3}\right): \delta 20.66\left(\mathrm{CH}_{3}\right), 52.56\left(\mathrm{OCH}_{3}\right), 118.46$ $(\mathrm{CH}=\mathrm{CH}), 127.16(\mathrm{Ar}-\mathrm{C}), 127.62(\mathrm{Ar}-\mathrm{C}), 131.11(\mathrm{Ar}-\mathrm{C})$, $131.75(\mathrm{Ar}-\mathrm{C}), 133.56(\mathrm{Ar}-\mathrm{C}), 138.66(\mathrm{Ar}-\mathrm{C}), 143.46(\mathrm{Ar}-\mathrm{C})$, 168.36 (CO); Anal. Calcd. (\%) for $\mathrm{C}_{11} \mathrm{H}_{12} \mathrm{O}_{2}: \mathrm{C}, 74.98 ; \mathrm{H}, 6.86$; Found: $\mathrm{C}, 74.90 ; \mathrm{H}, 6.80$.

\subsubsection{Synthesis of (E)-methyl 3-(2-hydroxy-5-methoxyphenyl) acrylate 20}

Yield\%-90, Mol. Wt.: 208.21, mp. $135-137{ }^{\circ} \mathrm{C} ;{ }^{1} \mathrm{H}$ NMR $\left(400 \mathrm{MHz}, \mathrm{CDCl}_{3}\right): \delta 3.48\left(3 \mathrm{H}, \mathrm{s}, \mathrm{OCH}_{3}\right) ; 3.89\left(3 \mathrm{H}, \mathrm{s}, \mathrm{OCH}_{3}\right)$; $5.09(1 \mathrm{H}, \mathrm{s}, \mathrm{OH}) ; 5.64(1 \mathrm{H}, \mathrm{d}, J=16.0 \mathrm{~Hz}, \mathrm{CH}=\mathrm{CH}) ; 6.66-6.69$ $(1 \mathrm{H}, \mathrm{dd}, J=1.5 \mathrm{~Hz}, J=8.0 \mathrm{~Hz}, \mathrm{Ar}-\mathrm{H}) ; 7.46(1 \mathrm{H}, \mathrm{d}, J=14.0 \mathrm{~Hz}$, $\operatorname{Ar}-\mathrm{H}) ; 8.58(1 \mathrm{H}, \mathrm{d}, J=16.0 \mathrm{~Hz}, \mathrm{Ar}-\mathrm{H}) ; 9.47(1 \mathrm{H}, \mathrm{d}, J=16.0 \mathrm{~Hz}$, $\mathrm{CH}=\mathrm{CH}) ; \mathrm{NMR}\left(100 \mathrm{MHz}, \mathrm{CDCl}_{3}\right): \delta 51.61\left(\mathrm{OCH}_{3}\right), 57.67$ $\left(\mathrm{OCH}_{3}\right), 107.67(\mathrm{Ar}-\mathrm{C}), 116.26(\mathrm{Ar}-\mathrm{C}), 119.16(\mathrm{CH}=\mathrm{CH})$, 122.20 (Ar-C), 131.09 (Ar-C), $141.21(\mathrm{Ar}-\mathrm{C}), 142.20$ $(\mathrm{CH}=\mathrm{CH}), 157.67$ (Ar-C), 168.22 (CO); Anal. Calcd. (\%) for $\mathrm{C}_{11} \mathrm{H}_{12} \mathrm{O}_{4}: \mathrm{C}, 63.45 ; \mathrm{H}, 5.81$; Found: $\mathrm{C}, 63.40 ; \mathrm{H}, 5.78$.
4.4.5 Synthesis of (E)-methyl 3-(5-fluoro-2-hydroxyphenyl) acrylate $\mathbf{2 1}$

White solid, Yield\%-90, Mol. Wt.: $196.18, \mathrm{mp} .132-134{ }^{\circ} \mathrm{C}$, ${ }^{1} \mathrm{H}$ NMR $\left(400 \mathrm{MHz}, \mathrm{CDCl}_{3}\right)$ : $\delta 3.84\left(\mathrm{~s}, 3 \mathrm{H}, \mathrm{CH}_{3}\right) ; 5.29(\mathrm{~s}, 1 \mathrm{H}$, $\mathrm{OH}) ; 5.46(\mathrm{~d}, 1 \mathrm{H}, J=16.0 \mathrm{~Hz}, \mathrm{CH}=\mathrm{CH}) ; 7.43(\mathrm{~d}, 1 \mathrm{H}, J=8.0 \mathrm{~Hz}$, Ar-H); 8.63-8.66 (dd, $1 \mathrm{H}, J=8.0 \mathrm{~Hz}, 4.0 \mathrm{~Hz}, \mathrm{Ar}-\mathrm{H}) ; 9.04$ (d, $1 \mathrm{H}, J=4 . \mathrm{Hz}, \mathrm{Ar}-\mathrm{H}) ; 9.56(\mathrm{~d}, 1 \mathrm{H}, J=16 \mathrm{~Hz}, \mathrm{CH}=\mathrm{CH}) ; \mathrm{NMR}$ $\left(100 \mathrm{MHz}, \mathrm{CDCl}_{3}\right): \delta 22.12\left(\mathrm{CH}_{3}\right), 119.26(\mathrm{CH}=\mathrm{CH}), 121.16$ $(\mathrm{Ar}-\mathrm{C}), 122.22(\mathrm{Ar}-\mathrm{C}), 132.12(\mathrm{Ar}-\mathrm{C}), 144.43(\mathrm{CH}=\mathrm{CH})$, 145.43 (Ar-C), 158.11 (C-F), 168.11 (CO), Anal. Calcd. (\%) for $\mathrm{C}_{10} \mathrm{H}_{9} \mathrm{FO}_{3}: \mathrm{C}, 61.22 ; \mathrm{H}, 4.62$; Found: $\mathrm{C}, 61.19 ; \mathrm{H}, 4.60$.

\subsubsection{Synthesis of (E)-methyl 3-(2-hydroxy-4-methylphenyl) acrylate 22}

White solid, Yield\%-90, mp. Mol. Wt.: 192.21, mp. 137-137 ${ }^{\circ} \mathrm{C},{ }^{1} \mathrm{H}$ NMR $\left(400 \mathrm{MHz}, \mathrm{CDCl}_{3}\right): \delta 2.20\left(\mathrm{~s}, 3 \mathrm{H}, \mathrm{CH}_{3}\right)$, $3.84\left(\mathrm{~s}, 3 \mathrm{H}, \mathrm{OCH}_{3}\right) ; 5.09(\mathrm{~s}, 1 \mathrm{H}, \mathrm{OH}) ; 6.23(\mathrm{~d}, 1 \mathrm{H}, J=16.0 \mathrm{~Hz}$, $\mathrm{CH}=\mathrm{CH}) ; 6.54(\mathrm{~s}, 1 \mathrm{H}, \mathrm{Ar}-\mathrm{H}) ; 7.48(\mathrm{~d}, 1 \mathrm{H}, J=8.0 \mathrm{~Hz}, \mathrm{Ar}-\mathrm{H})$; $8.66(\mathrm{~d}, 1 \mathrm{H}, J=8.0 \mathrm{~Hz}, \mathrm{Ar}-\mathrm{H}) ; 9.46(\mathrm{~d}, 1 \mathrm{H}, J=16.0 \mathrm{~Hz}$, $\mathrm{CH}=\mathrm{CH})$; NMR $\left(100 \mathrm{MHz}, \mathrm{CDCl}_{3}\right): \delta 21.10\left(\mathrm{CH}_{3}\right), 51.10$ $\left(\mathrm{OCH}_{3}\right), 101.12(\mathrm{Ar}-\mathrm{C}), 116.11(\mathrm{Ar}-\mathrm{C}), 118.16(\mathrm{CH}=\mathrm{CH})$, 121.121 (Ar-C), 131.18 (Ar-C), 140.11 (Ar-C), 142.10 $(\mathrm{CH}=\mathrm{CH}), 156.10(\mathrm{Ar}-\mathrm{C}), 161.12(\mathrm{CO})$; Anal. Calcd. (\%) for $\mathrm{C}_{11} \mathrm{H}_{12} \mathrm{O}_{3}: \mathrm{C}, 68.74 ; \mathrm{H}, 6.29$; Found: $\mathrm{C}, 68.74 ; \mathrm{H}, 6.20$.

\subsubsection{Synthesis of (E)-butyl} 3-(2-hydroxy-5-methoxyphenyl) acrylate 23

White crystalline solid, Yield\%-85, Mol. Wt.: 250.29, mp. 135-137 ${ }^{\circ} \mathrm{C},{ }^{1} \mathrm{H}$ NMR $\left(400 \mathrm{MHz}, \mathrm{CDCl}_{3}\right): \delta 0.97(\mathrm{t}, 3 \mathrm{H}$, $\left.J=16.4 \mathrm{~Hz}, \mathrm{CH}_{3}\right) ; 1.39-1.57\left(\mathrm{~m}, 2 \mathrm{H}, \mathrm{CH}_{2}\right) ; 1.66-1.76(\mathrm{~m}, 2 \mathrm{H}$, $\left.\mathrm{CH}_{2}\right) ; 3.81\left(\mathrm{~s}, 3 \mathrm{H}, \mathrm{OCH}_{3}\right), 4.24\left(\mathrm{t}, 2 \mathrm{H}, J=16.4 \mathrm{~Hz}, \mathrm{CH}_{2}\right) ; 5.45$ $(\mathrm{s}, 1 \mathrm{H}, \mathrm{OH}) ; 6.60(\mathrm{~d}, 1 \mathrm{H}, J=16.4 \mathrm{~Hz}, \mathrm{CH}=\mathrm{CH}) ; 6.88(\mathrm{~d}, 1 \mathrm{H}$, $J=16.4 \mathrm{~Hz}, \mathrm{Ar}-\mathrm{H}) ; 7.15(\mathrm{~d}, 1 \mathrm{H}, J=16.0 \mathrm{~Hz}, \mathrm{Ar}-\mathrm{H}) ; 7.54(\mathrm{~s}, 1 \mathrm{H}$, $\mathrm{Ar}-\mathrm{H})$; $8.05(\mathrm{~d}, 1 \mathrm{H}, J=13.6, \mathrm{CH}=\mathrm{CH})$. NMR (100 MHz, CDCl $)_{3}$ : $\delta$ 13.83 $\left(\mathrm{CH}_{3}\right), 16.81\left(\mathrm{CH}_{2}\right), 30.15\left(\mathrm{CH}_{2}\right), 35.36\left(\mathrm{CH}_{2}\right), 66.24$ $\left(\mathrm{CH}_{2}\right), 118.37(\mathrm{CH}=\mathrm{CH}), 119.36(\mathrm{Ar}-\mathrm{C}), 123.22(\mathrm{Ar}-\mathrm{C}), 126.10$ $(\mathrm{Ar}-\mathrm{C}), 127.59(\mathrm{Ar}-\mathrm{C}), 137.78(\mathrm{Ar}-\mathrm{C}), 138.34(\mathrm{CH}=\mathrm{CH})$, 155.13 (Ar-C), 167.12 (CO). Anal. Calcd. (\%) for $\mathrm{C}_{14} \mathrm{H}_{18} \mathrm{O}_{4}$ : C, 67.18; H, 7.25; Found: C, 67.10; H, 7.20;

\subsubsection{Synthesis of (E)-butyl 3-(5-amino-2-hydroxyphenyl) acrylate 24}

Light brown crystalline solid, Yield\% $86, \mathrm{mp} .135-137^{\circ} \mathrm{C}$, 140-142 Mol. Wt.: 235.28, ${ }^{1} \mathrm{H}$ NMR ( $\left.400 \mathrm{MHz}, \mathrm{CDCl}_{3}\right): \delta 0.96$ $\left(\mathrm{t}, 3 \mathrm{H}, J=14.8 \mathrm{~Hz}, \mathrm{CH}_{3}\right) ; 1.39-1.48\left(\mathrm{~m}, 2 \mathrm{H}, \mathrm{CH}_{2}\right) ; 1.66-1.73$ $\left(\mathrm{m}, 2 \mathrm{H}, \mathrm{CH}_{2}\right) ; 3.58\left(\mathrm{~s}, 2 \mathrm{H}, \mathrm{NH}_{2}\right) ; 4.23\left(\mathrm{t}, 2 \mathrm{H}, 16.0 \mathrm{~Hz}, \mathrm{CH}_{2}\right)$; $5.58(\mathrm{~s}, 1 \mathrm{H}, \mathrm{OH}) ; 6.60(\mathrm{~d}, 1 \mathrm{H}, J=16.0 \mathrm{~Hz}, \mathrm{CH}=\mathrm{CH}) ; 6.87(\mathrm{~d}$, $1 \mathrm{H}, J=12.4 \mathrm{~Hz}, \mathrm{Ar}-\mathrm{H}) ; 7.16(\mathrm{~d}, 1 \mathrm{H}, J=16 \mathrm{~Hz}, \mathrm{Ar}-\mathrm{H}) ; 7.52(\mathrm{~s}$, 
$1 \mathrm{H}, \mathrm{Ar}-\mathrm{H}) ; 7.94(\mathrm{~d}, 1 \mathrm{H}, J=16.0 \mathrm{~Hz}, \mathrm{CH}=\mathrm{CH}) . \mathrm{NMR}(100 \mathrm{MHz}$, $\left.\mathrm{CDCl}_{3}\right): \delta 16.63\left(\mathrm{CH}_{3}\right), 18.62\left(\mathrm{CH}_{2}\right), 31.65\left(\mathrm{CH}_{2}\right), 64.26\left(\mathrm{CH}_{2}\right)$, $116.66(\mathrm{CH}=\mathrm{CH}), 119.65(\mathrm{Ar}-\mathrm{C}), 121.12(\mathrm{Ar}-\mathrm{C}), 127.80$ $(\mathrm{Ar}-\mathrm{C}), 129.99(\mathrm{Ar}-\mathrm{C}), 136.80(\mathrm{Ar}-\mathrm{C}), 138.33(\mathrm{CH}=\mathrm{CH})$, 157.60 (Ar-C), 167.77 (CO). Anal. Calcd. (\%) for $\mathrm{C}_{13} \mathrm{H}_{17} \mathrm{NO}_{3}$ : $C, 66.36 ; H, 7.28 ; N, 5.95$; Found: $C, 66.30 ; H, 7.20 ; N, 5.90$.

\subsubsection{Synthesis of (E)-butyl 3-(5-chloro-2-hydroxyphenyl) acrylate $\mathbf{2 5}$}

White crystalline solid, Yield\%-84, mp. $148-150^{\circ} \mathrm{C} ;$ Mol. Wt.: 254.71, ${ }^{1} \mathrm{H}$ NMR $\left(400 \mathrm{MHz}, \mathrm{CDCl}_{3}\right): \delta 0.96(\mathrm{t}, 3 \mathrm{H}, J=16 \mathrm{~Hz}$, $\left.\mathrm{CH}_{3}\right) ; 1.32-1.49\left(\mathrm{~m}, 2 \mathrm{H}, \mathrm{CH}_{2}\right) ; 1.45-1.92\left(\mathrm{~m}, 2 \mathrm{H}, \mathrm{CH}_{2}\right) ; 4.33(\mathrm{t}$, $\left.2 \mathrm{H}, J=16.0 \mathrm{~Hz}, \mathrm{CH}_{2}\right) ; 5.11(\mathrm{~s}, 1 \mathrm{H}, \mathrm{OH}) ; 6.60(\mathrm{~d}, 1 \mathrm{H}, J=16.0 \mathrm{~Hz}$, $\mathrm{CH}=\mathrm{CH}) ; 6.77(\mathrm{~d}, 1 \mathrm{H}, J=14 \mathrm{~Hz}, \mathrm{Ar}-\mathrm{H}) ; 7.25(\mathrm{~d}, 1 \mathrm{H}, J=\mathrm{Hz}$, $\mathrm{Ar}-\mathrm{H}) ; 7.59(\mathrm{~s}, 1 \mathrm{H}, \mathrm{Ar}-\mathrm{H}) ; 7.96(\mathrm{~d}, 1 \mathrm{H}, J=14.8 \mathrm{~Hz}, \mathrm{CH}=\mathrm{CH})$. NMR $\left(100 \mathrm{MHz}, \mathrm{CDCl}_{3}\right): \delta 14.13\left(\mathrm{CH}_{3}\right), 19.82\left(\mathrm{CH}_{2}\right), 31.66$ $\left(\mathrm{CH}_{2}\right), 64.66\left(\mathrm{CH}_{2}\right), 117.16(\mathrm{CH}=\mathrm{CH}), 119.16(\mathrm{Ar}-\mathrm{C}), 123.82$ $(\mathrm{Ar}-\mathrm{C}), 125.10(\mathrm{Ar}-\mathrm{C}), 128.79(\mathrm{Ar}-\mathrm{C}), 130.08(\mathrm{Ar}-\mathrm{C}), 139.64$ $(\mathrm{CH}=\mathrm{CH}), 154.61$ (Ar-C), $168.72(\mathrm{CO})$; Anal. Calcd. (\%) for $\mathrm{C}_{13} \mathrm{H}_{15} \mathrm{ClO}_{3}: \mathrm{C}, 61.30 ; \mathrm{H}, 5.94$; Found: $\mathrm{C}, 61.25 ; \mathrm{H}, 5.90$;

\subsubsection{Synthesis of (E)-ethyl 3-(2-hydroxy-5-methoxyphenyl) acrylate 26}

White solid, Yield-88\%, mp. 141-143 ${ }^{\circ} \mathrm{C}$, Mol. Wt.: 222.24, ${ }^{1} \mathrm{H}$ NMR $\left(400 \mathrm{MHz}, \mathrm{CDCl}_{3}\right): \delta 1.37\left(\mathrm{t}, 3 \mathrm{H}, J=16 \mathrm{~Hz}, \mathrm{CH}_{3}\right) ; 3.17$ $\left(\mathrm{s}, 3 \mathrm{H}, \mathrm{OCH}_{3}\right) ; 4.23-4.33\left(\mathrm{q}, 2 \mathrm{H}, \mathrm{CH}_{2}\right) ; 5.18(\mathrm{~s}, 1 \mathrm{H}, \mathrm{OH}) ; 6.83$ $(\mathrm{d}, 1 \mathrm{H}, J=16.4 \mathrm{~Hz}, \mathrm{CH}=\mathrm{CH}) ; 6.89(\mathrm{~s}, 1 \mathrm{H}, \mathrm{Ar}-\mathrm{H}) ; 6.95(\mathrm{~d}, 1 \mathrm{H}$, $J=8.0, \operatorname{Ar}-\mathrm{H}) ; 7.32(\mathrm{~d}, 1 \mathrm{H}, J=14.0 \mathrm{~Hz}, \mathrm{Ar}-\mathrm{H}), 7.83(\mathrm{~d}, 1 \mathrm{H}$, $J=16.4 \mathrm{~Hz}, \mathrm{CH}=\mathrm{CH})$; NMR $\left(100 \mathrm{MHz}, \mathrm{CDCl}_{3}\right): \delta 15.25\left(\mathrm{CH}_{3}\right)$, $30.36\left(\mathrm{OCH}_{3}\right), 60.99\left(\mathrm{CH}_{2}\right), 117.84(\mathrm{Ar}-\mathrm{C}), 117.49(\mathrm{Ar}-\mathrm{C})$, $122.45(\mathrm{C}=\mathrm{C}), 129.09(\mathrm{C}=\mathrm{C}), 142.22(\mathrm{Ar}-\mathrm{C}), 143.12(\mathrm{Ar}-\mathrm{C})$, 156.21 (Ar-C), 169.23 (CO). Anal. Calcd. (\%) for $\mathrm{C}_{12} \mathrm{H}_{14} \mathrm{O}_{4}: \mathrm{C}$, 64.85; H, 6.35; Found: $\mathrm{C}, 64.80 ; \mathrm{H}, 6.30$.

\subsubsection{Synthesis of (E)-ethyl 3-(5-fluoro-2-hydroxyphenyl) acrylate 27}

White solid, Yield-85\%, mp. $150-152^{\circ} \mathrm{C}$, Mol. Wt.: 210.2, ${ }^{1} \mathrm{H}$ NMR $\left(400 \mathrm{MHz}, \mathrm{CDCl}_{3}\right): \delta 1.36(\mathrm{t}, 3 \mathrm{H}, J=16.8 \mathrm{~Hz}$, $\left.\mathrm{CH}_{3}\right), 4.20-4.33\left(\mathrm{q}, 2 \mathrm{H}, \mathrm{CH}_{2}\right) ; 5.10(\mathrm{~s}, 1 \mathrm{H}, \mathrm{OH}) ; 6.87(\mathrm{~d}, 1 \mathrm{H}$, $J=15.6 \mathrm{~Hz}, \mathrm{CH}=\mathrm{CH}) ; 6.94(\mathrm{~d}, 1 \mathrm{H}, J=9.6, \mathrm{Ar}-\mathrm{H}) ; 7.38(\mathrm{~d}, 1 \mathrm{H}$, $J=12.0 \mathrm{~Hz}, \mathrm{Ar}-\mathrm{H}) ; 7.89(\mathrm{~d}, 1 \mathrm{H}, J=4.0 \mathrm{~Hz}, \mathrm{Ar}-\mathrm{H}) ; 8.45(\mathrm{~d}$, $1 \mathrm{H}, J=17.2 \mathrm{~Hz}, \mathrm{CH}=\mathrm{CH})$; NMR $\left(100 \mathrm{MHz}, \mathrm{CDCl}_{3}\right): \delta 15.71$ $\left(\mathrm{CH}_{3}\right), 60.19\left(\mathrm{CH}_{2}\right), 119.14(\mathrm{Ar}-\mathrm{C}), 121.41(\mathrm{Ar}-\mathrm{C}), 122.23$ $(\mathrm{Ar}-\mathrm{C}), 124.33(\mathrm{C}=\mathrm{C}), 128.38(\mathrm{C}=\mathrm{C}), 142.44(\mathrm{Ar}-\mathrm{C}), 144.45$ $(\mathrm{Ar}-\mathrm{C}), 158.21$ (Ar-C), 170.10 (CO). Anal. Calcd. (\%) for $\mathrm{C}_{11} \mathrm{H}_{11} \mathrm{FO}_{3}: \mathrm{C}, 62.85 ; \mathrm{H}, 5.27$; Found: $\mathrm{C}, 62.79 ; \mathrm{H}, 5.20$.
4.4.12 Synthesis of (E)-ethyl 3-(5-chloro-2-hydroxyphenyl) acrylate $\mathbf{2 8}$

White solid, Yield-87\%, mp. $144-146^{\circ} \mathrm{C}$, Mol. Wt.: 226.66, ${ }^{1} \mathrm{H}$ NMR (400 MHz, $\left.\mathrm{CDCl}_{3}\right): \delta 1.38\left(\mathrm{t}, 3 \mathrm{H}, J=16.0 \mathrm{~Hz}, \mathrm{CH}_{3}\right)$; $4.14\left(\mathrm{q}, 2 \mathrm{H}, \mathrm{CH}_{2}\right) ; 5.17(\mathrm{~s}, 1 \mathrm{H}, \mathrm{OH}) ; 6.83(\mathrm{~d}, 1 \mathrm{H}, J=16.0 \mathrm{~Hz}$, $\mathrm{CH}=\mathrm{CH}) ; 6.89(\mathrm{~s}, 1 \mathrm{H}, \mathrm{Ar}-\mathrm{H}) ; 6.97(\mathrm{~d}, 1 \mathrm{H}, J=16.8, \mathrm{Ar}-\mathrm{H})$; $7.35(\mathrm{~d}, 1 \mathrm{H}, J=16.0 \mathrm{~Hz}, \mathrm{Ar}-\mathrm{H}) ; 7.73(\mathrm{~d}, 1 \mathrm{H}, J=16.0 \mathrm{~Hz}$, $\mathrm{CH}=\mathrm{CH}) ; \mathrm{NMR}\left(100 \mathrm{MHz}, \mathrm{CDCl}_{3}\right): \delta 15.75\left(\mathrm{CH}_{3}\right), 60.19$ $\left(\mathrm{CH}_{2}\right), 119.94(\mathrm{Ar}-\mathrm{C}), 120.49(\mathrm{Ar}-\mathrm{C}), 123.83(\mathrm{Ar}-\mathrm{C}), 125.33$ $(C=C), 128.98(C=C), 142.54(\mathrm{Ar}-\mathrm{C}), 143.42(\mathrm{Ar}-\mathrm{C}), 157.11$ (Ar-C), 171.12 (CO). Anal. Calcd. (\%) for $\mathrm{C}_{11} \mathrm{H}_{11} \mathrm{ClO}_{3}$ : C, 58.29; $H, 4.89$; Found: $C, 58.20 ; H, 4.80$.

\subsubsection{Synthesis of (E)-ethyl 3-(2-hydroxy-5-methylphenyl) acrylate $\mathbf{2 9}$}

White solid, Yield-90\%, mp. 141-143 ${ }^{\circ} \mathrm{C}$, Mol. Wt.: 206.24, ${ }^{1} \mathrm{H}$ NMR $\left(400 \mathrm{MHz}, \mathrm{CDCl}_{3}\right)$ : $\delta 1.35\left(\mathrm{t}, 3 \mathrm{H}, J=17.2 \mathrm{~Hz}, \mathrm{CH}_{3}\right)$; $2.18\left(\mathrm{~s}, 3 \mathrm{H}, \mathrm{Ar}-\mathrm{CH}_{3}\right) ; 4.29\left(\mathrm{q}, 2 \mathrm{H}, \mathrm{CH}_{2}\right) ; 5.18(\mathrm{~s}, 1 \mathrm{H}, \mathrm{OH})$; $6.67(\mathrm{~d}, 1 \mathrm{H}, J=16.8 \mathrm{~Hz}, \mathrm{CH}=\mathrm{CH}) ; 6.95(\mathrm{~d}, 1 \mathrm{H}, J=8.0 \mathrm{~Hz}$, $\operatorname{Ar}-\mathrm{H}) ; 7.31(\mathrm{~d}, 1 \mathrm{H}, J=8.0, \mathrm{Ar}-\mathrm{H}) ; 7.81(\mathrm{~s}, 1 \mathrm{H}, \mathrm{Ar}-\mathrm{H}), 8.02$ $(\mathrm{d}, 1 \mathrm{H}, J=16.0 \mathrm{~Hz}, \mathrm{CH}=\mathrm{CH})$; NMR $\left(100 \mathrm{MHz}, \mathrm{CDCl}_{3}\right): \delta$ $14.25\left(\mathrm{CH}_{3}\right), 21.36\left(\mathrm{Ar}-\mathrm{CH}_{3}\right), 60.69\left(\mathrm{CH}_{2}\right), 116.80(\mathrm{Ar}-\mathrm{C})$, $116.99(\mathrm{Ar}-\mathrm{C}), 118.87(\mathrm{Ar}-\mathrm{C}), 121.45(\mathrm{C}=\mathrm{C}), 129.09(\mathrm{C}=\mathrm{C})$, $141.19(\mathrm{Ar}-\mathrm{C}), 142.32(\mathrm{Ar}-\mathrm{C}), 155.71(\mathrm{Ar}-\mathrm{C}), 169.12(\mathrm{CO})$. Anal. Calcd. (\%) for $\mathrm{C}_{12} \mathrm{H}_{14} \mathrm{O}_{3}$ : C, 69.88; $\mathrm{H}, 6.84$; Found: $\mathrm{C}$, 69.80; H, 6.79.

Acknowledgements We would like to express our deepest appreciation to the Ministry of Science and Technology, Government of the Peoples' Republic of Bangladesh (Grant No.: 39.00.0000.012.02.009.17-474/23.2018-2019) for providing the financial assistance to perform the research work.

\section{Compliance with ethical standards}

Conflict of interest The authors confirm no conflicts of interest.

\section{References}

1. Sobhani S, Zarifi F (2015) Pd-isatin Schiff base complex immobilized on $\gamma$-Fe2O3 as a magnetically recyclable catalyst for the Heck and Suzuki cross-coupling reactions. Cuihua Xuebao Chin J Catal 36:555-563

2. Bagherzadeh $M$, Amini $M$, Derakhshandeh PG, Haghdoost MM (2014) An efficient glucose-based ligand for Heck and Suzuki coupling reactions in aqueous media. J Iran Chem Soc 11:441-446

3. Nadri S, Joshaghani M, Rafiee E (2009) Biphenyl-based phosphine: a well-defined, air-stable, and efficient ligand for the Mizoroki-Heck reaction. Appl Catal A Gen 362:163-168

4. Heck RF (1979) Palladium-catalyzed reactions of organic halides with olefins. Acc Chem Res 12:146-151 
5. Nabid MR, Bide Y, Tabatabaei Rezaei SJ (2011) Pd nanoparticles immobilized on PAMAM-grafted MWCNTs hybrid materials as new recyclable catalyst for Mizoraki-Heck cross-coupling reactions. Appl Catal A Gen 406:124-132

6. Guo CS, Weng CM, Hong FE (2010) Preparation of cobalt-containing ligands with $\mathrm{NHC}$ - and/or P-coordinating sites and their application in heck reactions: the formation of an unexpected cobalt-containing zwitterionic complex. Eur J Inorg Chem 2010:3220-3228

7. Chen Q, Gao K, Peng C, Xie H, Zhao ZK, Bao M (2015) Preparation of lignin/glycerol-based bis(cyclic carbonate) for the synthesis of polyurethanes. Green Chem 17:4546-4551

8. Kim SW, Kim M, Lee WY, Hyeon T (2002) Fabrication of hollow palladium spheres and their successful application to the recyclable heterogeneous catalyst for Suzuki coupling reactions. J Am Chem Soc 124:7642-7643

9. Metin Ö, Mazumder V, Özkar S, Sun S (2010) Monodisperse nickel nanoparticles and their catalysis in hydrolytic dehydrogenation of ammonia borane. J Am Chem Soc 132:1468-1469

10. Hammann JM, Haas D, Knochel P (2015) Cobalt-catalyzed Negishi cross-coupling reactions of (hetero)arylzinc reagents with primary and secondary alkyl bromides and iodides. Angew Chem Int Ed 54:4478-4481

11. Qi H, Zhang W, Wang X, Li H, Chen J, Peng K, Shao M (2009) Heck reaction catalyzed by flower-like cobalt nanostructures. Catal Commun 10:1178-1183

12. Chang CP, Pradiuldi SV, Hong FE (2009) Synthesis of coumarin derivatives by palladium complex catalyzed intramolecular Heck reaction: preparation of a 1,2-cyclobutadiene-substituted $\mathrm{CpCoCb}$ diphosphine chelated palladium complex. Inorg Chem Commun 12:596-598

13. Affo $W$, Ohmiya $H$, Fujioka $T$, Ikeda $Y$, Nakamura T, Yorimitsu $H$, Oshima K, Imamura Y, Mizuta T, Miyoshi K (2006) Cobalt-catalyzed trimethylsilylmethylmagnesium-promoted radical alkenylation of alkyl halides: a complement to the Heck reaction. J Am Chem Soc 128:8068-8077

14. Pal A, Sevonkaev I, Bartling B, Rijssenbeek J, Goia DV (2014) Dipentaerythritol: a novel additive for the precipitation of dispersed Ni particles in polyols. RSC Adv 4:20909-20914

15. Di LX, Chen H, Liu SS, Ye LQ, Li YP (2015) Hydrothermal synthesis of superparamagnetic $\mathrm{Fe}_{3} \mathrm{O}_{4}$ nanoparticles with ionic liquids as stabilizer. Mater Res Bull 62:217-221

16. Lu W, Yao K, Wang J, Yuan J (2015) lonic liquids-water interfacial preparation of triangular Ag nanoplates and their shape-dependent antibacterial activity. J Colloid Interface Sci 437:35-41

17. Darwich W, Gedig C, Srour H, Santini CC, Prechtl MHG (2013) Single step synthesis of metallic nanoparticles using dihydroxyl functionalized ionic liquids as reductive agent. RSC Adv 3:20324-20331

18. Pachón LD, Rothenberg G (2008) Transition-metal nanoparticles: synthesis, stability and the leaching issue. Appl Organomet Chem 22:288-299

19. Evano G, Blanchard N, Toumi M (2008) Copper-mediated coupling reactions and their applications in natural products and designed biomolecules synthesis. Chem Rev 108:3054-3131

20. Chen A, Zhao G, Chen J, Chen L, Yu Y (2013) Selective hydrogenation of phenol and derivatives over an ionic liquid-like copolymer stabilized palladium catalyst in aqueous media. RSC Adv 3:4171-4175

21. Lozinskaya El, Shaplov AS, Kotseruba MV, Komarova LI, Lyssenko KA, Antipin MY, Golovanov DG, Vygodskii YS (2006) "One-pot" synthesis of aromatic poly (1,3,4-oxadiazole) $\mathrm{s}$ in novel solvents—ionic liquids. J Polym Sci, Part A: Polym Chem 44:380-394
22. McAtee JR, Martin SES, Cinderella AP, Reid WB, Johnson KA, Watson DA (2014) The first example of nickel-catalyzed silylHeck reactions: direct activation of silyl triflates without iodide additives. Tetrahedron 70:4250-4256

23. Wagner ML, Schmidt LD (1995) Model catalytic oxidation reactions: oxygen with $\mathrm{H} 2, \mathrm{NH} 3$, and $\mathrm{N} 2 \mathrm{H} 4$ on $\mathrm{Rh}(111)$. J Phys Chem 99:805-815

24. Bridger K, Watts J, Chien CL (1988) The dependence of coercivities of ultrafine Fe particles on packing fraction and microstructure. J Appl Phys 63:3233-3235

25. Martın JI, Nogues J, Liu K, Vicent JL, Schuller IK (2003) Ordered magnetic nanostructures: fabrication and properties. J Magn Magn Mater 256:449-501

26. Kuroda CS, Maeda M, Nishibiraki H, Matsushita N, Handa $H$, Abe M (2005) Styrene-coated iron nanobeads for medical use. IEEE Trans Magn 41:4117-4119

27. Myers VS, Weir MG, Carino EV, Yancey DF, Pande S, Crooks RM (2011) Dendrimer-encapsulated nanoparticles: new synthetic and characterization methods and catalytic applications. Chem Sci 2:1632-1646

28. Peng X, Pan Q, Rempel GL (2008) Bimetallic dendrimer-encapsulated nanoparticles as catalysts: a review of the research advances. Chem Soc Rev 37:1619-1628

29. Andrés R, De Jesús E, Flores JC (2007) Catalysts based on palladium dendrimers. New J Chem 31:1161-1191

30. Crooks RM, Zhao M, Sun L, Chechik V, Yeung LK (2001) Dendrimer-encapsulated metal nanoparticles: synthesis, characterization, and applications to catalysis. Acc Chem Res 34:181-190

31. Fei Z, Geldbach TJ, Zhao D, Dyson PJ (2006) From dysfunction to bis-function: on the design and applications of functionalised ionic liquids. Chem Eur J 12:2122-2130

32. Zhao D, Fei Z, Geldbach TJ, Scopelliti R, Dyson PJ (2004) Nitrilefunctionalized pyridinium ionic liquids: synthesis, characterization, and their application in carbon-carbon coupling reactions. J Am Chem Soc 126:15876-15882

33. Wan H, Li S, Konovalova TA, Zhou Y, Thrasher JS, Dixon DA, Street SC (2009) Experimental and theoretical studies of the photoreduction of metal ion - dendrimer complexes: observation of a delocalized organic radical. J Phys Chem C 113:5358-5367

34. Luo X, Imae T (2007) Photochemical synthesis of crown-shaped platinum nanoparticles using aggregates of G4-NH 2 PAMAM dendrimer as templates. J Mater Chem 17:567-571

35. Juttukonda V, Paddock RL, Raymond JE, Denomme D, Richardson AE, Slusher LE, Fahlman BD (2006) Facile synthesis of tin oxide nanoparticles stabilized by dendritic polymers. J Am Chem Soc 128:420-421

36. Shi X, Wang S, Meshinchi S, Van Antwerp ME, Bi X, Lee I, Baker JR Jr (2007) Dendrimer-entrapped gold nanoparticles as a platform for cancer-cell targeting and imaging. Small 3:1245-1252

37. Antonietti M, Wenz E, Bronstein L, Seregina M (1995) Synthesis and characterization of noble metal colloids in block copolymer micelles. Adv Mater 7:1000-1005

38. O'Brien JM, Hoveyda AH (2011) Metal-free catalytic C-Si bond formation in an aqueous medium. Enantioselective NHCcatalyzed silyl conjugate additions to cyclic and acyclic a, $\beta$-unsaturated carbonyls. J Am Chem Soc 133:7712-7715

39. Wan H, Li S, Konovalova TA, Zhou Y, Thrasher JS, Dixon DA, Street SC (2009) Experimental and theoretical studies of the photoreduction of metal ion - dendrimer complexes: observation of a delocalized organic radical. J Phys Chem C 113:5358-5367

40. Ahmed K, Tariq I, Siddiqui SU, Mudassir M (2016) Green synthesis of cobalt nanoparticles by using methanol extract of plant leaf as reducing agent. Pure Appl Biol 5:453

41. Caló V, Nacci A, Monopoli A, Detomaso A, lliade P (2003) Pd nanoparticle catalyzed Heck arylation of 1, 1-disubstituted alkenes 
in ionic liquids. Study on factors affecting the regioselectivity of the coupling process. Organometallics 22:4193-4197

42. Beccaria L, Deagostino A, Prandi C, Zavattaro C, Venturello P (2006) Heck reaction on 1-alkoxy-1, 3-dienes in ionic liquids: a superior medium for the regioselective arylation of the conjugated dienic system. Synlett 18:2989-2992

43. Zhang Z, Wang Z (2006) Diatomite-supported Pd nanoparticles: an efficient catalyst for Heck and Suzuki reactions. J Org Chem 71:7485-7487

44. Dupont J, Scholten JD (2010) On the structural and surface properties of transition-metal nanoparticles in ionic liquids. Chem Soc Rev 39:1780-1804

45. Begouin JM, Gosmini C (2009) Cobalt-catalyzed cross-coupling between in situ prepared arylzinc halides and 2-chloropyrimidine or 2-chloropyrazine. J Org Chem 74(8):3221-3224

46. Pachon LD, Rothenberg G (2008) Transition-metal nanoparticles: synthesis, stability and the leaching issue. Appl Organometal Chem 22(6):288-299

47. Ott LS, Hornstein BJ, Finke RG (2006) A test of the transitionmetal nanocluster formation and stabilization ability of the most common polymeric stabilizer, poly (vinylpyrrolidone), as well as four other polymeric protectants. Langmuir 22(22):9357-9367

48. Hornstein BJ, Finke RG (2003) Transition-metal nanocluster catalysts: scaled-up synthesis, characterization, storage conditions, stability, and catalytic activity before and after storage of polyoxoanion-and tetrabutylammonium-stabilized Ir (0) nanoclusters. Chem Mater 15(4):899-909

49. Prechtl MH, Scholten JD, Dupont J (2010) Carbon-carbon cross coupling reactions in ionic liquids catalysed by palladium metal nanoparticles. Molecules 15(5):3441-3461

50. Shan S, Wu J, Kang N, Cronk H, Zhao Y, Zhao W, Skeete Z, Joseph P, Trimm B, Luo J, Zhong CJ (2015) Nanoscale alloying in electrocatalysts. Catalysts 5(3):1465-1478

51. Ikeda Y, Nakamura T, Yorimitsu H, Oshima K (2002) Cobalt-catalyzed Heck-type reaction of alkyl halides with styrenes. J Am Chem Soc 124:6514-6515
52. Cahiez G, Moyeux A (2010) Cobalt-catalyzed cross-coupling reactions. Chem Rev 110(3):1435-1462

53. Kreyenschmidt F, Meurer SE, Koszinowski K (2019) Mechanisms of cobalt/phosphine-catalyzed cross-coupling reactions. Chem A Eur J 25(23):5912-5921

54. Qi H, Zhang W, Wang X, Li H, Chen J, Peng K, Shao M (2009) Heck reaction catalyzed by flower-like cobalt nanostructures. Catal Commun 10(8):1178-1183

55. lyer S, Thakur VV (2000) The novel use of $\mathrm{Ni} \mathrm{Co}, \mathrm{Cu}$ and Mn heterogeneous catalysts for the Heck reaction. J Mol Catal A: Chem 157(1-2):275-278

56. Zhou P, Li Y, Sun P, Zhou J, Bao J (2007) A novel Heck reaction catalyzed by Co hollow nanospheres in ligand-free condition. Chem Commun 14:1418-1420

57. Zhu Z, Ma J, Xu L, Xu L, Li H, Li H (2012) Facile synthesis of Co-B amorphous alloy in uniform spherical nanoparticles with enhanced catalytic properties. ACS Catal 2(10):2119-2125

58. Hajipour AR, Khorsandi Z (2016) Multi walled carbon nanotubes supported $\mathrm{N}$-heterocyclic carbene-cobalt (II) as a novel, efficient and inexpensive catalyst for the Mizoroki-Heck reaction. Catal Commun 77:1-4

59. Hajipour AR, Khorsandi Z, Karimi H (2015) Cobalt nanoparticles supported on ionic liquid-functionalized multiwall carbon nanotubes as an efficient and recyclable catalyst for Heck reaction. Appl Organometal Chem 29(12):805-808

60. Wakabayashi K, Yorimitsu H, Oshima K (2001) Cobalt-catalyzed tandem radical cyclization and cross-coupling reaction: its application to benzyl-substituted heterocycles. J Am Chem Soc 123:5374-5375

Publisher's Note Springer Nature remains neutral with regard to jurisdictional claims in published maps and institutional affiliations. 